Access this article online

Quick Response Code:

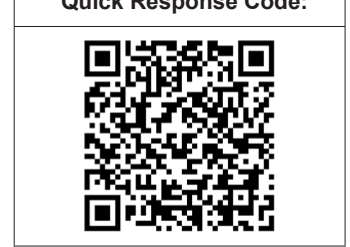

Website:

www.ijp-online.com

DOI:

10.4103/ijp.IJP_312_18
${ }^{1}$ Department of

Pharmacology, EMAN

Testing and Research

Laboratory, School

of Pharmaceutical

Sciences, Universiti

Sains Malaysia, Minden,

Penang, ${ }^{2}$ Department

of Pharmaceutical

Engineering, Faculty of

Engineering Technology,

University Malaysia

Pahang, Gambang,

${ }^{3}$ Advanced Oleochemicals

Technology Research

Division, Malaysian

Palm Oil Board, Kajang,

Selangor, ${ }^{4}$ Faculty

of Medicine, Quest

International University

Perak, Ipoh, Perak,

Malaysia, ${ }^{5} \mathrm{ACRF}$

Department of Cancer Biology and Therapeutics,

The John Curtin School

of Medical Research,

Australian National

University, Canberra,

Australia

Address for correspondence:

Dr. Mansoureh Nazari Vishkaei,

Department of

Pharmacology, EMAN

Testing and Research

Laboratory, School of

Pharmaceutical Sciences, Universiti Sains Malaysia,

Minden, 11800, Pulau

Penang, Malaysia.

E-mail: nazarimansoure@ gmail.com

Submission: 17-08-2018

Accepted: 04-03-2019

\title{
Antiangiogenic activity of sophorolipids extracted from refined bleached deodorized palm olein
}

\author{
Shazmin Kithur Mohamed ${ }^{1}$, Muhammad Asif', Mansoureh Vishkaei Nazari'1, \\ Hussein M. Baharetha', Syed Mahmood ${ }^{2}$, Abdul Rashid M. Yatim ${ }^{3}$, \\ Aman Shah Abdul Majid ${ }^{4}$, Amin Malik Shah Abdul Majid ${ }^{1,5}$
}

\section{Abstract:}

OBJECTIVES: Sophorolipids (SLS) are a group of surface-active glycolipids produced by a type of nonpathogenic yeast Candida bombicola in the presence of vegetable oil through fermentation technology. SLs have shown antitumor activity; however, the mechanism of action underlying the anticancer activity of SLs is poorly understood. This work evaluated the anticancer activity of SLS fermented from palm oil by exploring its antiangiogenic activity.

MATERIALS AND METHODS: The SLs that were fermented and further characterized for their biochemical activities. Cytotoxicity study was performed to assess cytostatic properties. A series of in vitro and ex vivo angiogenesis assay was also carried out. The relative fold change in the expression of p53 mRNA by SLs was also studied.

RESULTS: Altogether, the data show that SLs derived from palm oil fermentation process inhibited neovascularization in the ex vivo tissue segments and also the endothelial cell proliferation between $50 \%$ and $65 \%$ inhibition as a whole. The palm oil derived SLs also caused downregulation of the suppression level of vascular endothelial growth factor and also upregulate the p53 mRNA level. The analytical studies revealed the presence of high amount of phenolic compounds but with relatively weak antioxidant activity. The gas chromatography-mass spectrometry studies revealed abundant amount of palmitic and oleic acid, the latter an established antiangiogenic agent, and the former being proangiogenic.

CONCLUSION: Therefore, it can be concluded from this study that SLs derived from fermented palm oil have potent antiangiogenic activity which may be attributed by its oleic acid component.

Keywords:

Antiangiogenic, anticancer, fermentation, palm oil, sophorolipids

\section{Introduction}

$A$ ngiogenesis means the growth of Anew blood vessels. It is an important natural process occurring in the body both in healthy and diseased conditions. Angiogenesis occurs in the healthy body for healing wounds and for restoring blood flow to tissues after injury or insult. It is also an essential process in the growth and spread of

This is an open access journal, and articles are distributed under the terms of the Creative Commons Attribution-NonCommercial-ShareAlike 4.0 License, which allows others to remix, tweak, and build upon the work non-commercially, as long as appropriate credit is given and the new creations are licensed under the identical terms.

For reprints contact: reprints@medknow.com cancer. Tumors grow and spread massively with the aid of continuous blood supply.

Biosurfactants are surface-active metabolites synthesized biologically by microorganisms. Biosurfactants are widely used in many industries because they are unique.$^{[1]}$ Most yeast biosurfactants have been typically identified as glycolipids. The most interesting glycolipids are sophorolipids (SLs) because SLs are biodegradable, possess low ecotoxicity, and are also producible in high yield. SLs can be synthesized fermentatively

How to cite this article: Kithur Mohamed S, Asif M, Nazari MV, Baharetha HM, Mahmood S, Yatim AR, et al. Antiangiogenic activity of sophorolipids extracted from refined bleached deodorized palm olein. Indian J Pharmacol 2019;51:45-54. 
only by a selected number on yeast species as they are known to be surface-active compounds. ${ }^{[2]}$ The nonpathogenic yeast Candida bombicola used in this fermentation process to produce SLs. C. bombicola uses glucose as the primary carbon source converting the fermentation medium and oil into SLs.

SLs are of growing commercial interest because they can be easily produced in extremely high yields from cheap raw materials, such as vegetable oils, n-alkanes, and industrial waste product. ${ }^{[2]}$

Palm oil-derived SLs have been demonstrated to have antioxidant properties, and some studies have shown that SLs have potent anticancer activity. ${ }^{[3]}$

\section{Materials and Methods}

3-(4, 5-Dimethylthiazol-2-yl)-2, 5-diphenyltetrazolium bromide (MTT) was purchased from Affymetrix, USA. C. bombicola 22214 and EA.hy926 were obtained from ATCC, USA. Calbiochem, USA, and Corning, USA, supplied fibrinogen and matrigel, respectively. Dulbecco's Modified Eagle's Medium Powder and Medium 199 were purchased from Gibco, Life Technology, UK. Yeast extract and yeast malt agar were purchased from HiMedia, India. Ascorbic acid, Folin-Ciocalteu reagent, gallic acid, hydrochloric acid, and methanol were acquired from Merck, Germany. Solvents were purchased from QReC, New Zealand. Raybio, USA supplied human vascular endothelial growth factor (VEGF) Assay Kit. Acetic acid, ferrous sulfate, sodium acetate trihydrate, and sodium carbonate were obtained from $\mathrm{R}$ and $\mathrm{M}$ Chemicals, Essex, UK. 2,2'-azinobis (3-ethylbenzthiazolinesulfonic acid), 2,4,6-tris(1-pyridyl)-5-triazine (TPTZ), aprotinin, $\mathrm{CaCl2}, \mathrm{C} 6 \mathrm{H} 12 \mathrm{O} 6$, crystal violet, 1, 1-diphenyl-2-picrylhydrazyl (DPPH), $\varepsilon$-aminocaproic acid, KH2PO4, L-glutamine, MgSO4.7H2O, Na2CO3, $\mathrm{NaCl}, \mathrm{Na} 2 \mathrm{SO} 4$, potassium persulfate, suramin, and thrombin 1000 unit were purchased from Sigma-Aldrich, Germany.

\section{Fermentation and recovery of sophorolipids}

Cultivation studies were carried out in a $1 \mathrm{~L}$ benchtop bioreactor (BioTron, Korea) with stirring rate of $400 \mathrm{rpm}$, $\mathrm{pH}$ at 5.5, and the run air to $1 \mathrm{v} / \mathrm{v}$. Seed medium consisting of $10 \%$ glucose, $0.5 \%$ yeast extract, and mineral salt was prepared and incorporated into the bioreactor vessel. The medium used contained (in $\mathrm{g} / \mathrm{L}$ ) yeast extract, 5.0; $\mathrm{Mg} \mathrm{SO}_{4} .7 \mathrm{H} 2 \mathrm{O}, 5.0: \mathrm{KH}_{2} \mathrm{PO}_{4^{\prime}}, 1.0 ; \mathrm{CaCl}_{2^{\prime}}$ 0.1; and $\mathrm{NaCl}, 0.1 .800 \mathrm{~mL}$ of cultivation medium, excluding glucose, was incorporated into the fermenter vessel. The $\mathrm{pH}$ of the medium in vessel was adjusted to 5.5. The bioreactor was let to run for 2 days. On day 2, palm oil was added into the fermenter vessel in a sterile condition. The fermentation process was stopped on day 6 .
Ethyl acetate and n-hexane were used to separate crude SLs from the fermentation product. The end product was dried overnight in an oven at $105^{\circ} \mathrm{C}$ to completely remove n-hexane and dried again in desiccator over anhydrous $\mathrm{Na}_{2} \mathrm{SO}_{4}$ for $48 \mathrm{~h}$ before weighing.

\section{Ultraviolet visible spectrophotometry}

Ultraviolet (UV) spectrum of SLs was recorded using Lambda $45 \mathrm{UV} / \mathrm{Vis}$ Spectrophotometer system (Perkin-Elmer, USA) and screened on spectra range of $500-200 \mathrm{~nm}$.

\section{Fourier transform-infrared spectrometry}

The infrared (IR) spectra were obtained on Fourier transform-IR (FT-IR) spectrometer (Thermo. Nicolet Nexus 670, Thermo Scientific, USA) system connected to OMNIC software (Thermo, Electron Corporation, USA). The spectra were measured within the range of $400-4000 \mathrm{~cm}^{-1}$.

\section{Gas chromatography-mass spectrometry}

Gas chromatography-mass spectrometry (GC-MS) (Agilent 6890N/5973I, USA) equipped with electrospray ionization was used. About $1 \mu \mathrm{L}$ of sample $(10 \mathrm{mg} / \mathrm{mL})$ was injected. A nonpolar HP-5MS capillary column $(0.25 \mathrm{~mm} \times 30 \mathrm{~m} \times 0.25 \mu \mathrm{m}$ film thickness) packaged with stationary phase and equipped with quadrupole detector was used. The temperature was increased to $305^{\circ} \mathrm{C}$ at a rate of $20^{\circ} \mathrm{C}$ / $\min$. The compound mass ranged between 35 and $700 \mathrm{~m} / \mathrm{z}$ at a scanning rate of $1 \mathrm{scan} /$ second, and mass spectra obtained were compared to the database from the National Institute of Standard and Technology 02 library. MSD ChemStation Data were connected to the system for data analysis.

\section{Estimation of total phenolic content}

Folin-Ciocalteu reagent, sodium carbonate, SLs, and distilled water were mixed in a test tube in a ratio of 5:15:1:79 to the final volume of $1000 \mu \mathrm{L}$. All the tubes were incubated for $2 \mathrm{~h}$ at room temperature. Then, $200 \mu \mathrm{L}$ of each mixture was added in a 96-well microplate. ${ }^{[4]}$ Distilled water was used as blank. The absorbance was recorded at $765 \mathrm{~nm}$, and the results expressed as $\mu$ g gallic acid/equivalent/mg dry extract.

\section{2, 2'-azino-bis(3-ethylbenzothiazoline-6-sulphonic acid (ABTS) scavenging activity}

$14 \mathrm{mmol} / \mathrm{L}$ of ABTS and $4.9 \mathrm{mmol} / \mathrm{L}$ of potassium persulfate of equal volumes were dissolved in deionized water and react in the dark at $25^{\circ} \mathrm{C}$ for $20 \mathrm{~h}$ to form the radical cation solution of (ABTS+). The solution was diluted and read at $734 \mathrm{~nm}$. Ascorbic acid was used as reference standard. The results were expressed as $\mathrm{IC}_{50}$. 


\section{1, 1-diphenyl-2-picrylhydrazyl free radical} scavenging assay

About $100 \mu \mathrm{L}$ of each sample (at six concentrations) was mixed with $100 \mu \mathrm{L}$ of DPPH dissolved in methanol $(200 \mu \mathrm{mol} / \mathrm{L})$ and incubated in a dark place at $25{ }^{\circ} \mathrm{C}$ for $30 \mathrm{~min}$. The remaining amount of DPPH was determined at $517 \mathrm{~nm}$. Ascorbic acid was used as reference standard.

\section{Ferric reducing antioxidant power assay}

$150 \mu \mathrm{L}$ ferric reducing antioxidant power (FRAP) solution $(300 \mathrm{mmol} / \mathrm{L}$ acetate buffer, $\mathrm{pH} 3.6,10 \mathrm{mmol} / \mathrm{L}$ TPTZ in $40 \mathrm{mmol} / \mathrm{L} \mathrm{HCl}$ and $20 \mathrm{mmol} / \mathrm{L} \mathrm{FeCl}_{3}$ in a ratio 10:1:1) was added to $50 \mu \mathrm{L}$ of each sample and incubated at room temperature for $8 \mathrm{~min}$ and read the absorbance at $600 \mathrm{~nm}$. Ferrous sulfate was used as reference standard. All results were expressed as $\mathrm{Fe}^{+2}$ equivalent/mg dry extract.

3-(4, 5-Dimethylthiazol-2-yl)-2, 5-diphen yltetraz olium bromide cell viability assay

EA.hy926 cells were treated with SLs and incubated at $37^{\circ} \mathrm{C}$ with $5 \% \mathrm{CO}_{2}$ in humid atmosphere for $48 \mathrm{~h}$. The solubilized formazan product was quantified using TECAN Microplate Reader to calculate the percentage inhibition of cell proliferation. ${ }^{[5]}$

\section{Rat aorta ring assay}

Thoracic aortas were removed from euthanized rats. The aortas were cross sectioned into small rings (approximately 1-mm thickness) and seeded individually in 48 -wells plate in $300 \mu \mathrm{L}$ serum-free M199 media containing $3 \mathrm{mg} / \mathrm{mL}$ fibrinogen and $5 \mathrm{mg} /$ $\mathrm{mL}$ aprotinin. Ten microliters of thrombin (50 NIH $\mathrm{U} / \mathrm{mL}$ in $1 \%$ bovine serum albumin in $0.15 \mathrm{M} \mathrm{NaCl}$ ) were added into each well and incubated at $37^{\circ} \mathrm{C}$ for $90 \mathrm{~min}$ to be solidified. A second layer (M199 medium supplemented with $20 \%$ HIFBS, $0.1 \%$ ć-aminocaproic acid, $1 \%$ L-glutamine, $2.5 \mu \mathrm{g} / \mathrm{mL}$ amphotericin $\mathrm{B}$, and $60 \mu \mathrm{g} / \mathrm{mL}$ gentamicin) was added into each well (300 $\mu \mathrm{L} /$ well). ${ }^{[6]}$ On day 5, aortic rings were photographed using an inverted microscope $(\times 40)$, and subsequently, the length of blood vessels outgrowth from the primary tissue explants was measured using ImageJ software. All experimental procedures were conducted following the Animal Ethics Guidelines of Universiti Sains Malaysia (USM/Animal Ethics Approval/2015/ [97] [713]).

\section{Colony formation assay}

EA.hy 926 cells were incubated for $12 \mathrm{~h}$ to facilitate their attachment. Colonies formed were then fixed with $4 \%$ paraformaldehyde and stained with $0.2 \%(\mathrm{w} / \mathrm{v})$ crystal violet. The colonies were counted under a stereomicroscope.

\section{Cell migration assay}

EA.hy926 cell line was treated with SLs at different concentrations and photographed at 0,6 , and $18 \mathrm{~h}$ using an inverted microscope. The migrated area was measured using ImageJ software to calculate the percentage inhibition of wound closure. ${ }^{[7]}$

\section{Tube formation assay}

EA.hy926 cells were treated with concentrations of SLs and incubated at $37^{\circ} \mathrm{C}$ for $24 \mathrm{~h}$ were added to 48 -well plates and allowed to polymerize in incubator for $45 \mathrm{~min}$ at $37^{\circ} \mathrm{C}$ and $5 \% \mathrm{CO}_{2}$. The cells were then harvested and seeded onto the matrigel-coated plates. The cells were imaged using an inverted microscope at low magnification and the network length and width were quantified using Wimasis software (Wimasis $\mathrm{GmbH}$ Munich, Germany) to measure the percentage inhibition of tube formation.

\section{Vascular endothelial growth factor expression} The VEGF concentration in EA.hy926 cells was determined using a human VEGF-165 ELISA kit (Raybio, USA).

\section{p53 transcription factor expression}

p53 transcription factor expression of SLs was measured using Cignal ${ }^{\mathrm{TM}}$ Finder reporter array system. $50 \mu \mathrm{L}$ of the transfection reagent $\left(\right.$ FuGENE $^{\circledR}$, Promega, USA), prepared to $6 \mu \mathrm{L} / \mu \mathrm{g}$ DNA in Opti-MEM medium, was added into each well of the array plate. The reaction mixture was incubated at room temperature for $20 \mathrm{~min}$. EA.hy926 cells $\left(5 \times 10^{4} /\right.$ $\mathrm{mL}$ ) were resuspended in Opti-MEM medium containing $10 \%$ FBS and 1\% nonessential amino acids without antibiotics. Cells were observed under green filter under fluorescent microscope (EVOS $\mathrm{fl}$, Digital microscopy group, USA). The transfection efficiency was calculated.

Dual-Glo luciferase reporter system (Promega, USA) was used to measure the luciferase signals for each pathway in control and treated cells. The results are presented as mean \pm standard deviation (SD) of relative fold change in the activity of each pathway $(n=2)$.

Relative fold change in activity

$$
=\left(\frac{\text { FR ratio of treament group }}{\text { FR ratio of control gorup }}\right)
$$

\section{Statistical analysis}

Results are presented as mean \pm SD of three independent experiments $(n=3)$. One-way ANOVA, followed by post hoc tukey was executed using GraphPad Prism (San Diego, CA, USA) software. 


\section{Results}

\section{Fermentation and recovery of sophorolipids}

A volume of $3 \mathrm{~L}$ of solvents was used to recover $1 \mathrm{~L}$ of SLs obtained at the end of fermentation. Total SLs yield obtained after recovery was $57.5 \mathrm{~g} / \mathrm{L}$. The SLs acquired appeared to be brown-colored oil. The appearance changes to yellowish solid at room temperature. The $\mathrm{pH}$ of the fermentation end product was 5.5.

\section{Ultraviolet-visible spectrophotometry}

Figure 1 shows the UV absorption spectrum of SLs. The spectra showed strong absorption at $\lambda_{\max } 200-210 \mathrm{~nm}$. Besides, SLs showed obvious peaks between $\lambda_{\max } 220$ and $290 \mathrm{~nm}$.

\section{Fourier transform-infrared spectrometry}

Figure 2 demonstrates FT-IR spectrum of SLs with wave number ranging from 1000 to $3000 \mathrm{~cm}^{-1}$. FT-IR spectrum demonstrates three sharp vibrational bands present at 2922.06, 2850.22, and $1740.64 \mathrm{~cm}^{-1}$, indicating the presence of $\mathrm{C}-\mathrm{H}$ and $\mathrm{C}=\mathrm{O}$ stretching which belongs to alcohol and aldehyde groups, respectively.

\section{Gas chromatography-mass spectrometry}

The GC-MS analysis of SLs demonstrates the presence of fatty acid in vast amount as depicted in Figure 3. Six compounds were found to have similarity more than 90\% in SLs which are myristic acid, pentadecyclic acid, palmitic acid, oleic acid, and ethyl oleate. Among these six compounds, palmitic acid, followed by oleic acid was found to be present in huge amount $(60.28 \%$ and $25.71 \%$, respectively).

\section{Antioxidant assays}

Table 1 shows the result obtained from different antioxidant assays of SLs. Based on Table 1, SLs exhibited weak antioxidant capacity.

\section{3-(4, 5-Dimethylthiazol-2-yl)-2, 5-diphenyltetraz olium bromide cell viability assay}

After $48 \mathrm{~h}$ of treatment, no significant difference was observed at concentrations 6,12 , and $25 \mu \mathrm{g} / \mathrm{mL}$ of SLs $(P>0.05)$. This shows that there is no sign of toxicity at these three doses. The $\mathrm{IC}_{50}$ value of SLs on EA.hy926 cells was $110.49 \pm 12.05 \mu \mathrm{g} / \mathrm{mL}$ which shows the noncytotoxic nature of SLs toward the cells [Figure 4].

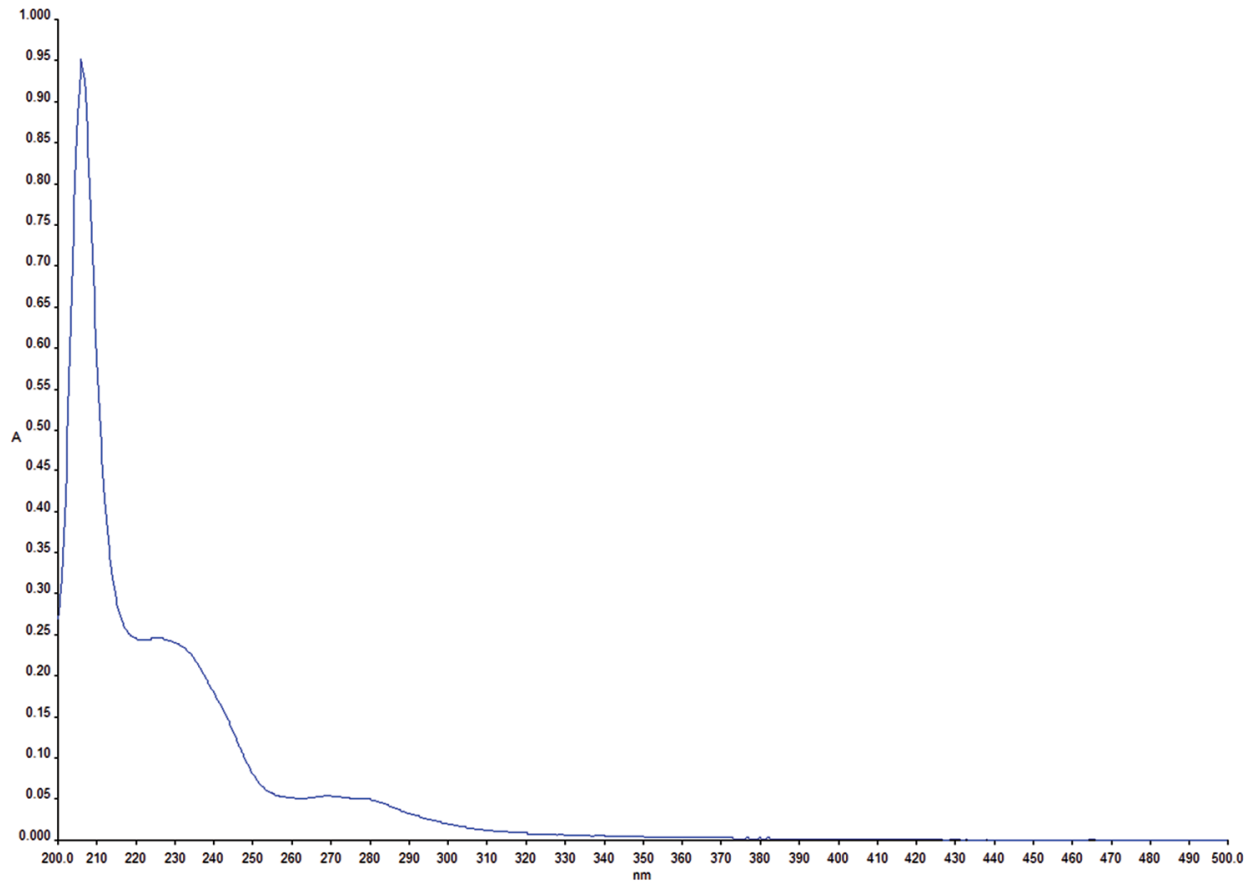

Figure 1: Ultraviolet-Vis absorption spectrum of sophorolipids

Table 1: Total phenolic contents and antioxidant values of sophorolipids

\begin{tabular}{|c|c|c|c|c|}
\hline Samples & TPC ( $\mu$ g gallic acid equivalent/mg extract) & ABTS $(\mu \mathrm{g} / \mathrm{mL})$ & DPPH $(\mu \mathrm{g} / \mathrm{mL})$ & FRAP (nmol Fe ${ }^{+2}$ equivalent/mg extract) \\
\hline SLs & $7.57 \pm 0.30$ & $473.24 \pm 34.87$ & $487.64 \pm 1.95$ & $64.67 \pm 0.25$ \\
\hline $\begin{array}{l}\text { Reference } \\
\text { (ascorbic acid) }\end{array}$ & - & $3.58 \pm 0.05$ & $0.98 \pm 0.02$ & - \\
\hline
\end{tabular}




\section{Rat aorta ring assay}

Figure 5 shows the antiangiogenic activity of SLs on rat aorta rings. At concentrations 6, 12, 25, 50, and $100 \mu \mathrm{g} / \mathrm{mL}$ of SLs and suramin at $100 \mu \mathrm{g} / \mathrm{mL}$, the percentage inhibition of blood vessel outgrowth was $19.57 \% \pm 13.09 \%, 28.65 \% \pm 10.45 \%, 33.69 \% \pm 5.98 \%$, $46.01 \% \pm 12.34 \%, 64.87 \% \pm 10.50 \%$, and $71.14 \% \pm 7.46 \%$, respectively [Figure 6]. There were no significant activities when the data of treatments at 6,12 , and $25 \mu \mathrm{g} / \mathrm{mL}$ of SLs were compared among each other $(P>0.05)$. At $50 \mu \mathrm{g} / \mathrm{mL}$, there were significant activities as compared to activities of treatment at lower doses $(P<0.001)$.

\section{Colony formation assay}

Figure 7 shows the potency of SLs to inhibit the colony formation of EA.hy926 cells. The percentage

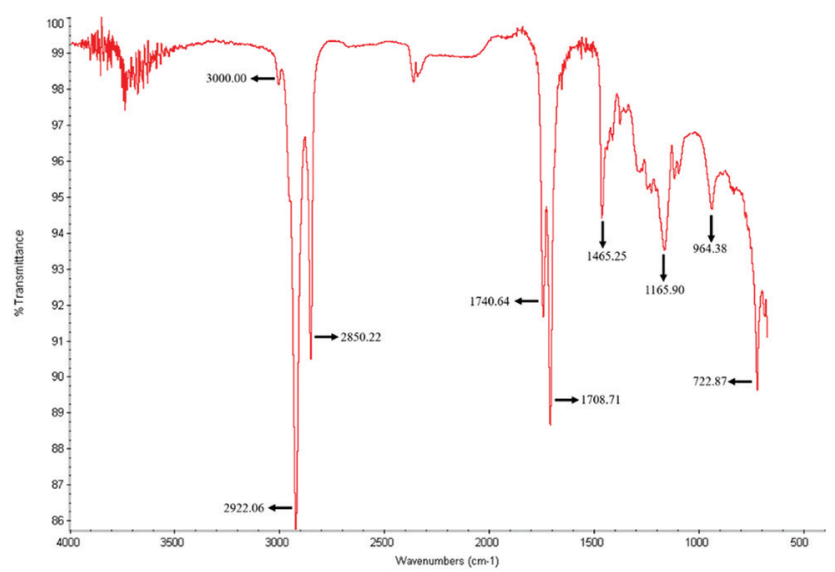

Figure 2: Fourier transform-infrared spectrum of sophorolipids illustrating the presence of major functional group of sophorolipids inhibition of colony formation at concentrations $50 \mu \mathrm{g} / \mathrm{mL}, 100 \mu \mathrm{g} / \mathrm{mL}$, and $100 \mu \mathrm{g} / \mathrm{mL}$ of suramin was $45.70 \% \pm 1.13 \%, 54.60 \% \pm 2.51 \%$, and $65.60 \% \pm 2.65 \%$, respectively [Figure 8]. Figure 7 (a) illustrates significant difference when the inhibitory activity of $50 \mu \mathrm{g} / \mathrm{mL}$ SLs was compared to suramin as positive control $(P<0.001)$.

\section{Cell migration assay}

Figure 9 shows the antimigratory activity of SLs on EA.hy926 cells at different treatment periods. The wound created in $0.5 \%$ DMSO group was closed after $18 \mathrm{~h}$ of treatment. The percentage of wound closure at $6 \mathrm{~h}$ in $0.5 \%$ DMSO, treatment groups ( 50 and $100 \mu \mathrm{g} / \mathrm{mL}$ of SLs), and $100 \mu \mathrm{g} / \mathrm{mL}$ of suramin was $30.43 \% \pm 6.63 \%, 14.60 \% \pm 6.59 \%$, $9.56 \% \pm 5.82 \%$, and $47.00 \% \pm 6.50 \%$, respectively [Figure 10 ]. After $6 \mathrm{~h}$ of treatment, the inhibitory activity of $50 \mu \mathrm{g} / \mathrm{mL}$ SLs was compared with the control group, and it showed significantly moderate activity $(P<0.01)$.

\section{Tube formation assay}

Figure 11 illustrates the tendency of SLs to inhibit EA.hy926 tube formation process. The percentage inhibition of tube formation at $50 \mu \mathrm{g} / \mathrm{mL}$ of SLs, $100 \mu \mathrm{g} / \mathrm{mL}$ of SLs, and $100 \mu \mathrm{g} / \mathrm{mL}$ of suramin was $47.40 \% \pm 19.20 \%, 52.20 \% \pm 14.90 \%$, and $76.70 \% \pm 4.38 \%$, respectively [Figure 12]. Based on Figure 12, the inhibitory activity of $100 \mu \mathrm{g} / \mathrm{mL}$ of SLs was almost the same as compared to suramin as positive control in equivalent concentration $(P>0.05)$.

\section{Determination of vascular endothelial growth factor}

Figure 13 highlights the amount of VEGF secreted by EA.hy926 cells in $0.5 \%$ DMSO, 50 and $100 \mu \mathrm{g} / \mathrm{mL}$ of

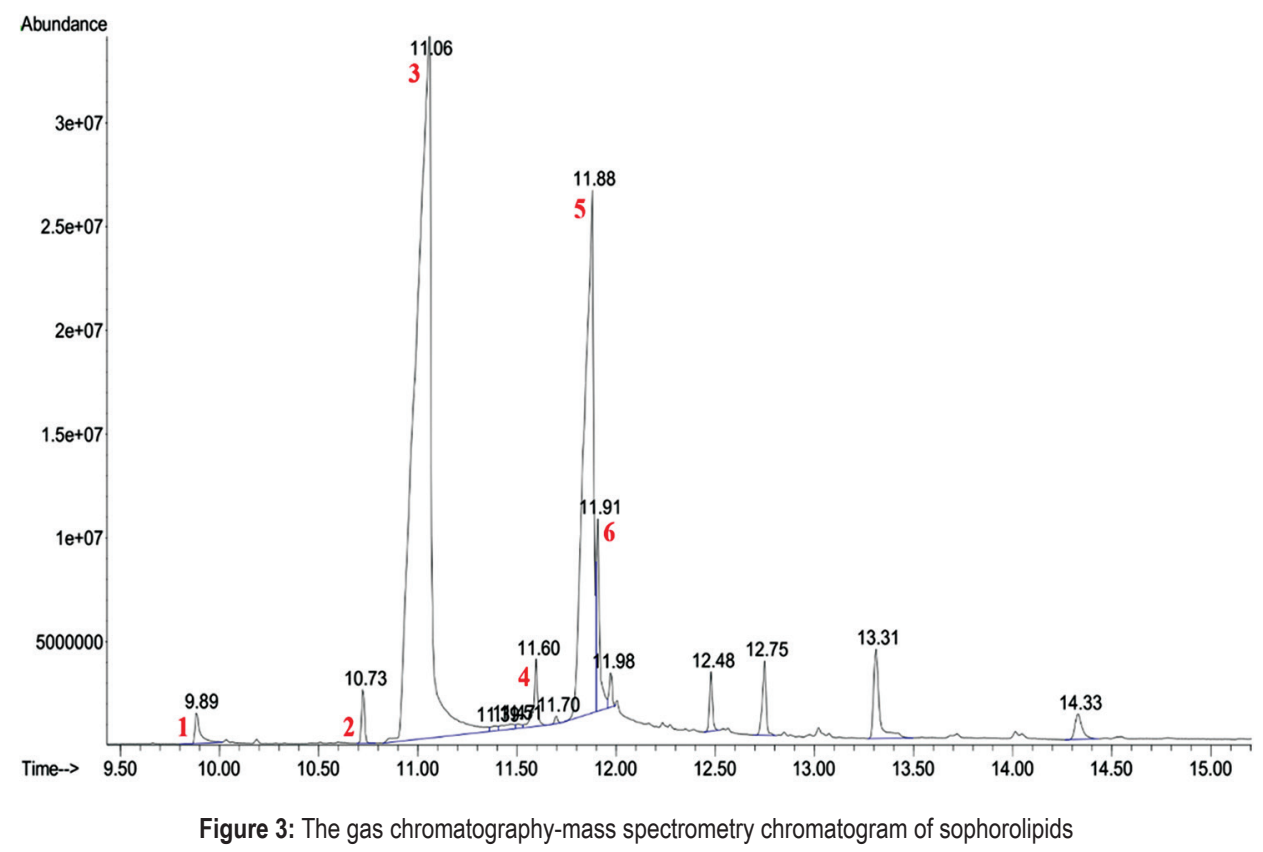




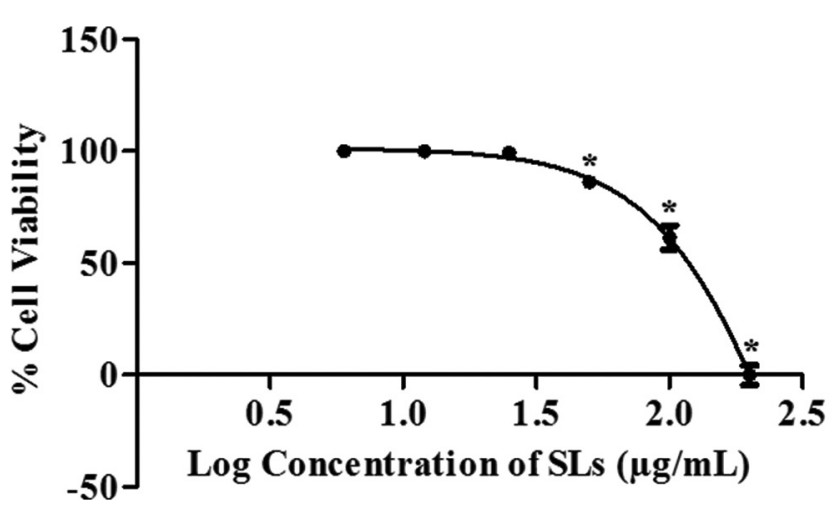

Figure 4: Effect of sophorolipids extract on cell viability of EA.hy926 cells after 48 hours of exposure to different concentrations. Values shown mean $\pm S D$ of three independent experiments $(n=3) .{ }^{*} P<0.05 . \mathrm{SD}=$ Standard deviation

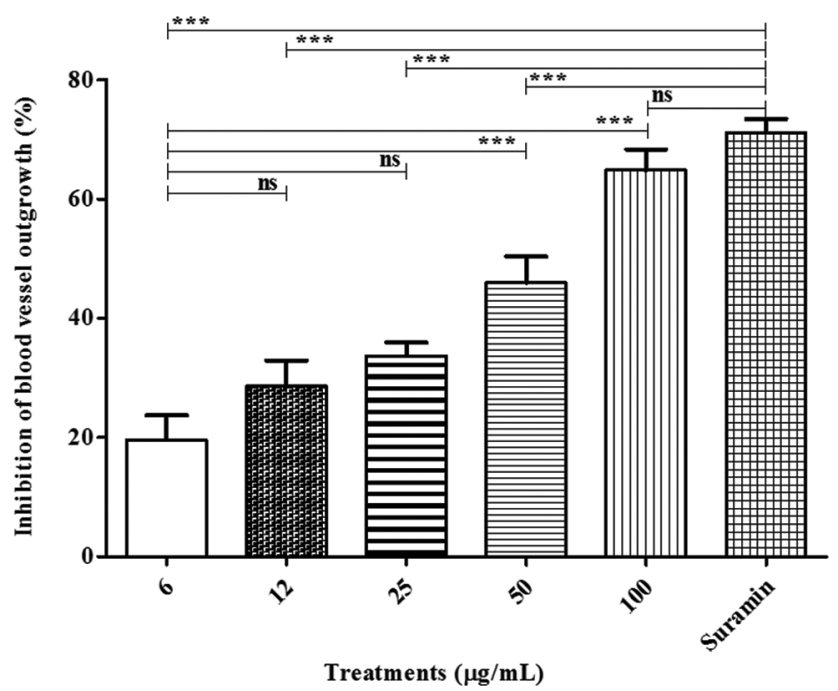

Figure 6: Dose-response relationship of different concentrations of SLs $(6-100 \mu \mathrm{g} / \mathrm{mL}$ ) against suramin (positive control). Values are presented as mean $\pm \mathrm{SD}(n=3) .{ }^{* * *} P<0.001$ and $n$ denotes $P>0.05$. SLs $=$ Sophorolipids, $\mathrm{SD}=$ Standard deviation, $\mathrm{ns}=$ Not significant

SLs and the percentage inhibition of VEGF release in the respective treatment groups. The VEGF concentrations released in $0.5 \%$ DMSO and 50 and $100 \mu \mathrm{g} / \mathrm{mL}$ of SLs were $71.40 \pm 9.52,45.60 \pm 4.02$, and $38.60 \pm 2.49 \mathrm{pg} / \mathrm{mL}$, respectively. There was a significant difference when the activities of 50 and $100 \mu \mathrm{g} / \mathrm{mL}$ treatment groups were compared to the control group $(P<0.01)$, whereas there was no statistical difference when the comparison was made between the treated groups $(P>0.05)$.

\section{p53 transcription factor expression}

Figure 14 shows the activity of SLs on the 533 transcription factor expression level. The relative fold change in p53 activity was $2.15 \pm 0.34$. Relative fold change value more than 1 designates the upregulation of p53 transcription factor. The activity of SLs at $100 \mu \mathrm{g} / \mathrm{mL}$ indicated significant difference by upregulating the activity of p53 transcription factors $(P<0.05)$.

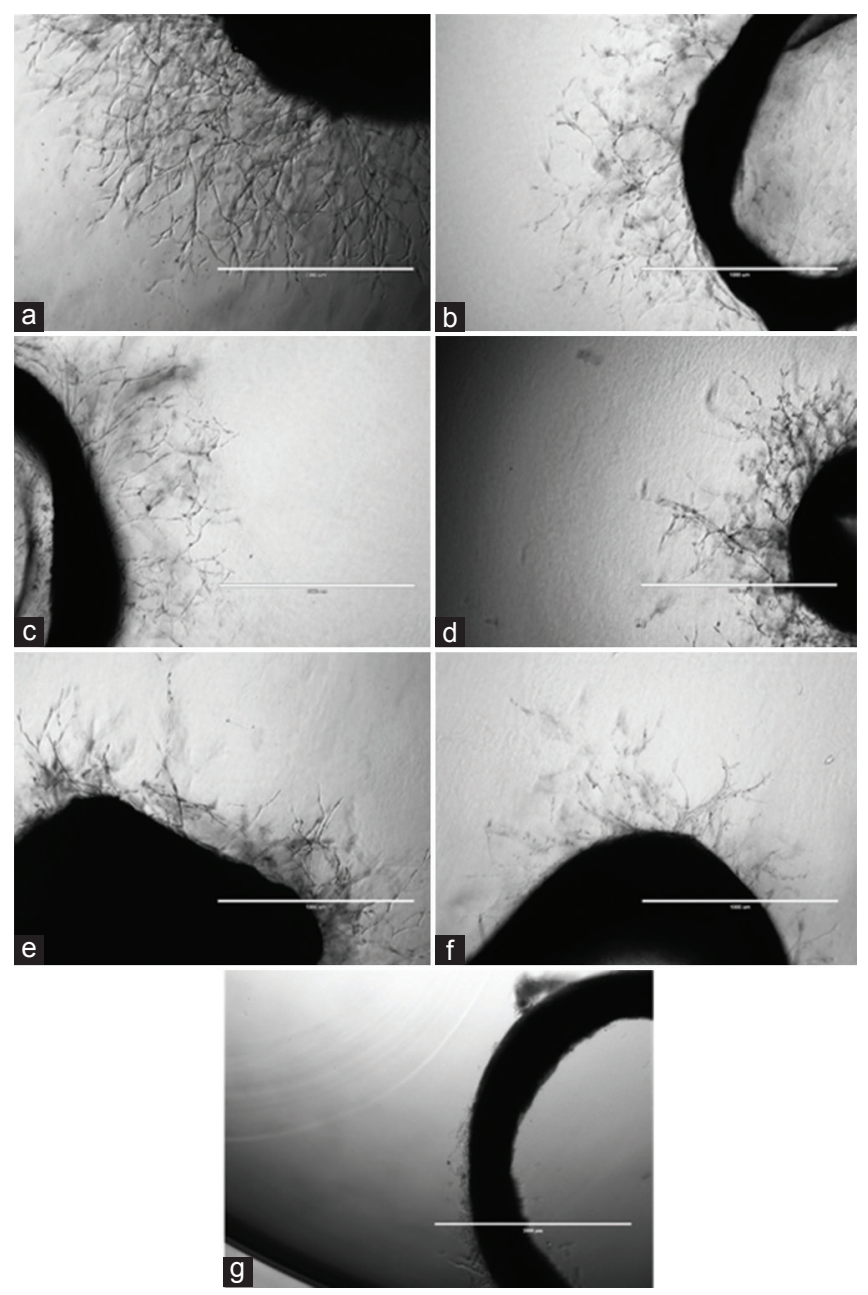

Figure 5: The antiangiogenic activity of SLs on blood vessel outgrowth in ex vivo rat aorta rings. The rings were treated with (a) $0.5 \% \mathrm{DMSO}$, (b) $6 \mu \mathrm{g} / \mathrm{mL}$ of SLs, (c) $12 \mu \mathrm{g} / \mathrm{mL}$ of SLs, (d) $25 \mu \mathrm{g} / \mathrm{mL}$ of SLs, (e) $50 \mu \mathrm{g} / \mathrm{mL}$ of SLs, (f) $100 \mu \mathrm{g} / \mathrm{mL}$ of SLs, and (g) $100 \mu \mathrm{g} / \mathrm{mL}$ of suramin as positive control. SLs = Sophorolipids, SD = Standard deviation, DMSO = Dimethyl sulfoxide, ns $=$ Not significant
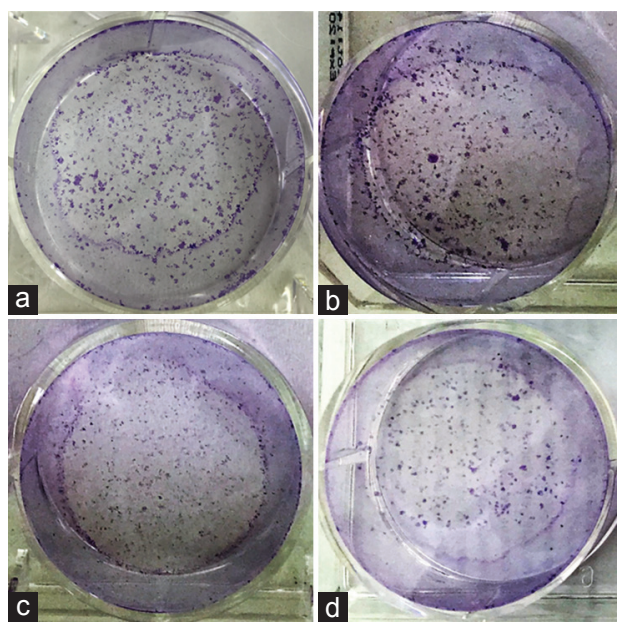

Figure 7: Effect of SLs treatment on clonogenic potential of EA.hy926 cells at concentrations (a) $0.5 \%$ DMSO, (b) $50 \mu \mathrm{g} / \mathrm{mL}$ of SLs, (c) $100 \mu \mathrm{g} / \mathrm{mL}$ of SLs, and (d) suramin $(100 \mu \mathrm{g} / \mathrm{mL})$. SLs $=$ Sophorolipids, DMSO = Dimethyl sulfoxide 


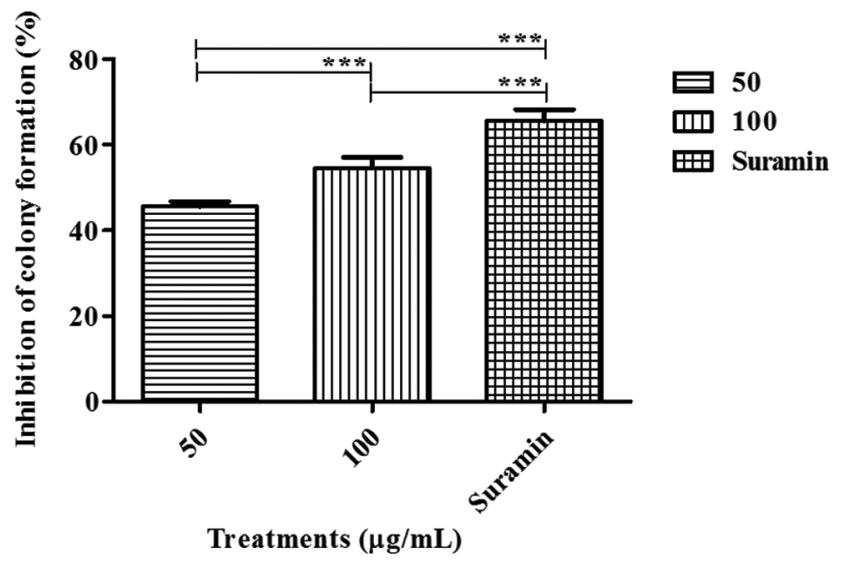

Figure 8: Graphical representation of percentage inhibition of colony at various treated concentrations. Control $=0.5 \%$ DMSO, $50=50 \mu \mathrm{g} / \mathrm{mL}$ of SLs, $C=100 \mu \mathrm{g} / \mathrm{mL}$ of SLs, and suramin $=100 \mu \mathrm{g} / \mathrm{mL}$ of suramin. Values are presented as mean $\pm \mathrm{SD}(n=3) .{ }^{* * *} P<0.001$. SLs $=$ Sophorolipids, $\mathrm{SD}=$ Standard deviation, DMSO = Dimethyl sulfoxide
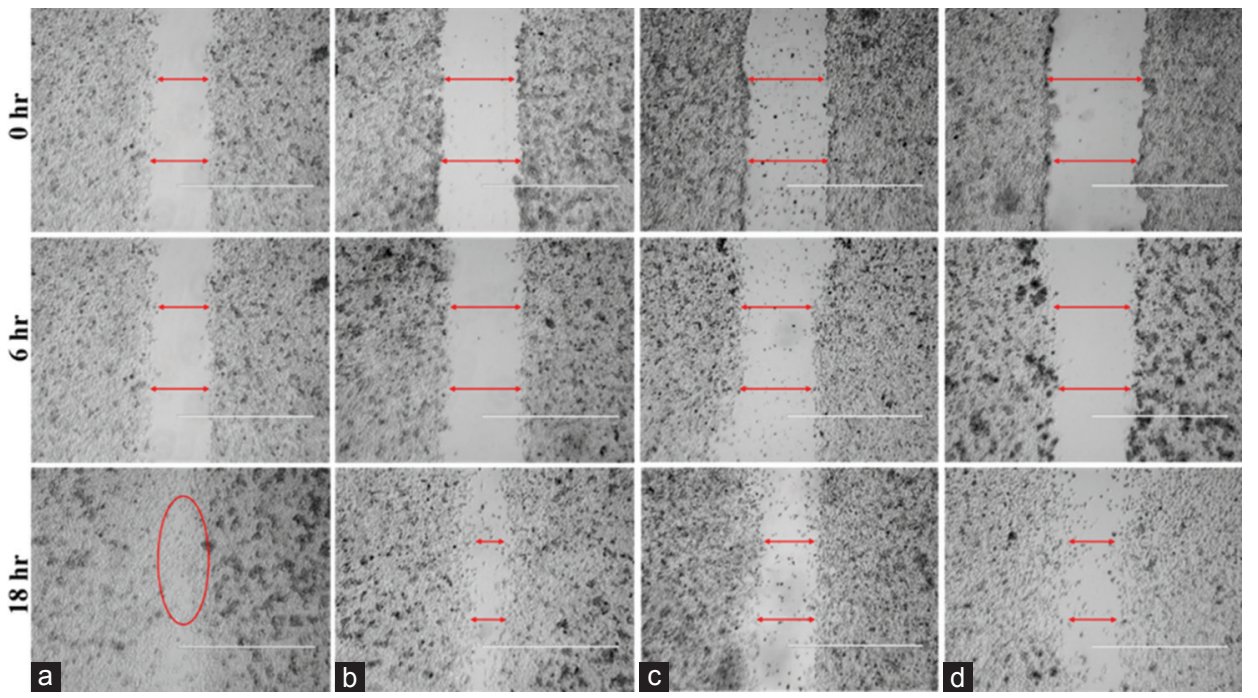

Figure 9: Effect of SLs on inhibition of EA.hy926 cell migration at concentrations (a) $0.5 \%$ DMSO, (b) $50 \mu \mathrm{g} / \mathrm{mL}$ of SLs, (c) $100 \mu \mathrm{g} / \mathrm{mL}$ of SLs, and (d) suramin (100 $\mu \mathrm{g} / \mathrm{mL}$ ) at 0,6 , and $18 \mathrm{~h}$. Photos were pictured at $\times 4(1000 \mu \mathrm{m}$ scale bar). SLs $=$ Sophorolipids, DMSO = Dimethyl sulfoxide
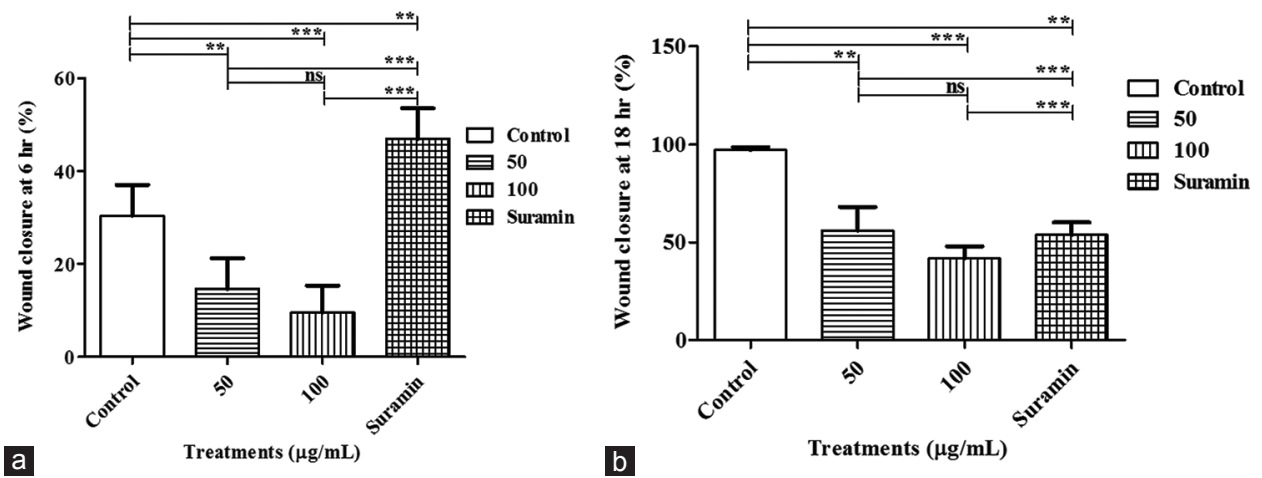

Figure 10: (a) Graphical representation of percentage of wound closure at $6 \mathrm{~h}$, (b) Graphical representation of percentage of wound closure at $18 \mathrm{~h}$. Control $=0.5 \%$ DMSO, $50=50 \mu \mathrm{g} / \mathrm{mL}$ of SLs, $100=100 \mu \mathrm{g} / \mathrm{mL}$ of SLs, and suramin $=100 \mu \mathrm{g} / \mathrm{mL}$ of suramin. Values are presented as mean $\pm \operatorname{SD}(n=3)$. ${ }^{* * *} P<0.001,{ }^{* *} P<0.01$, and ns denotes $P>0.05$. DMSO=Dimethyl sulfoxide, $S L s=S o p h o r o l i p i d s, S D=S t a n d a r d ~ d e v i a t i o n, n s=N o t$ significant 


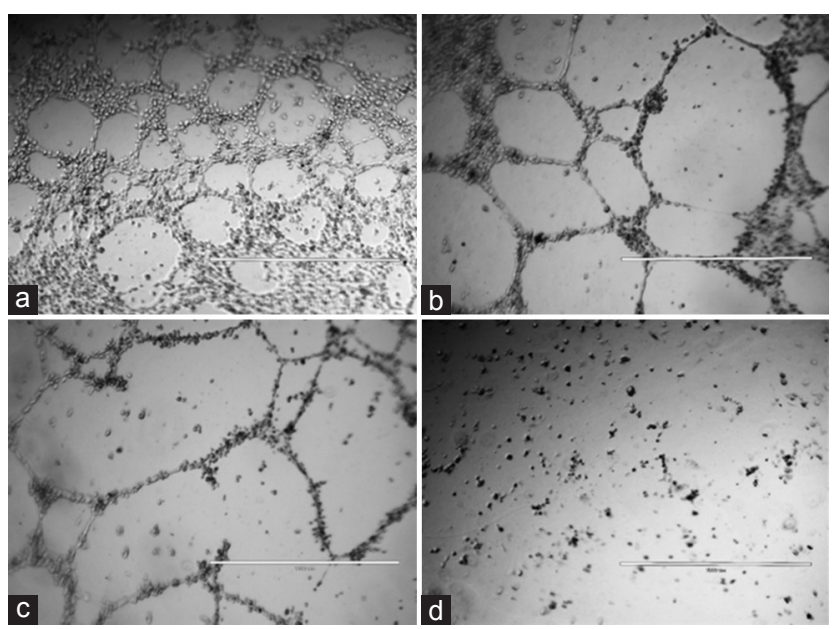

Figure 11: Antiangiogenic activity of SLs on EA.hy 926 cell tube formation at concentrations (a) $0.5 \%$ DMSO, (b) $50 \mu \mathrm{g} / \mathrm{mL}$ of SLs, (c) $100 \mu \mathrm{g} / \mathrm{mL}$ of SLs, and (d) suramin $(100 \mu \mathrm{g} / \mathrm{mL})$. Tubes were photographed at $\times 4$ (scale bar $1000 \mu \mathrm{m}$ ). DMSO = Dimethyl sulfoxide, SLs $=$ Sophorolipids

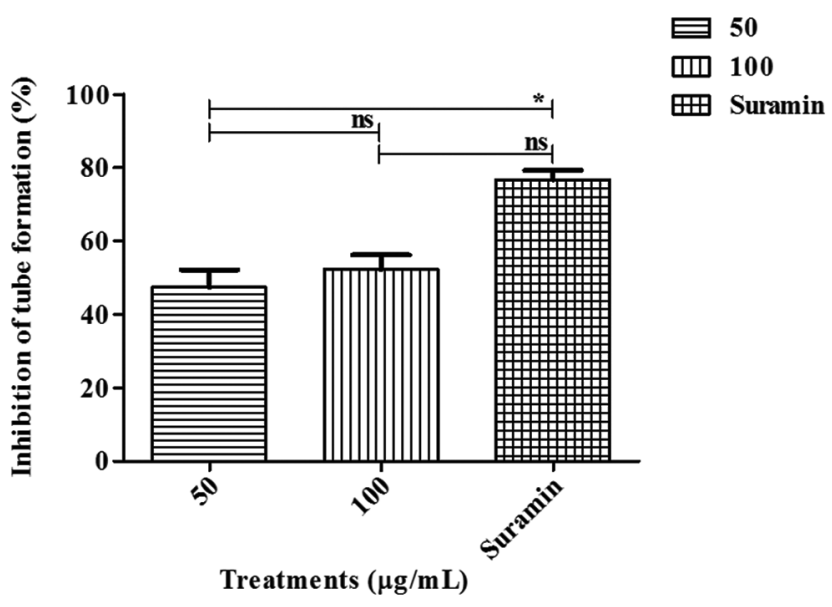

Figure 12: Graphical representation of percentage inhibition of tube formation. Control $=0.5 \%$ DMSO, $50=50 \mu \mathrm{g} / \mathrm{mL}$ of SLs, $100=100 \mu \mathrm{g} / \mathrm{mL}$ of SLs, and suramin $=100 \mu \mathrm{g} / \mathrm{mL}$ of suramin. Values are presented as mean $\pm \mathrm{SD}(n=3)$. ${ }^{*} P<0.05$ and ns denotes $P>0.05$. SLs $=$ Sophorolipids, DMSO $=$ Dimethyl sulfoxide, $\mathrm{SD}=$ Standard deviation, $\mathrm{ns}=$ Not significant
The result of FT-IR analysis matches the peaks obtained, which was reported in previous study of SLs. The maximum UV absorption of SLs in the present study, which is within $\lambda_{\max } 200-210 \mathrm{~nm}$, matches the outcome obtained in previous studies which have been used for high-performance liquid chromatography analysis. ${ }^{[1]}$ SLs were subjected to GC-MS analysis to investigate the type of compounds present in the extract. The presence of six compounds based on GC-MS data were fatty acids. Among all the antioxidant assays conducted together with estimation of total phenolic content, FRAP assay is a major contributor toward the antioxidant activity of SLs. On the other hand, phenolic content presents in SLs, ABTS and DPPH assays did not give rise to the antioxidant capacity of SLs, although they could accelerate SLs' activity at the least.

The result obtained from antiangiogenic activity of SLs using rat aorta ring assay demonstrated significant inhibition of the sprouting blood vessels with an $\mathrm{IC}_{50}$ of $63.89 \mu \mathrm{g} / \mathrm{mL}$. Hence, the findings from MTT assay and rat aorta ring assay on EA.hy926 cells reveal the antiangiogenic activity of SLs. Since SLs did not show any cytotoxic effect toward the cell, the antiangiogenic property could be mainly due to the inhibition property of SLs in the first stage of angiogenesis process. Colony formation assay results also confirmed the MTT assay results.

SLs in migration assay would have possibly inhibited the cell migration to prevent their penetration by downregulating VEGF. ${ }^{[12]}$ SLs in the tube formation study inhibited the tube formation of endothelial cells by $52 \%$ which is almost comparable to the percentage inhibition obtained from previous assays. ${ }^{[13]}$

VEGF plays a major role in the angiogenesis process. An extensive range of living organisms' tissues express VEGF at a very low level. However, VEGF is secreted
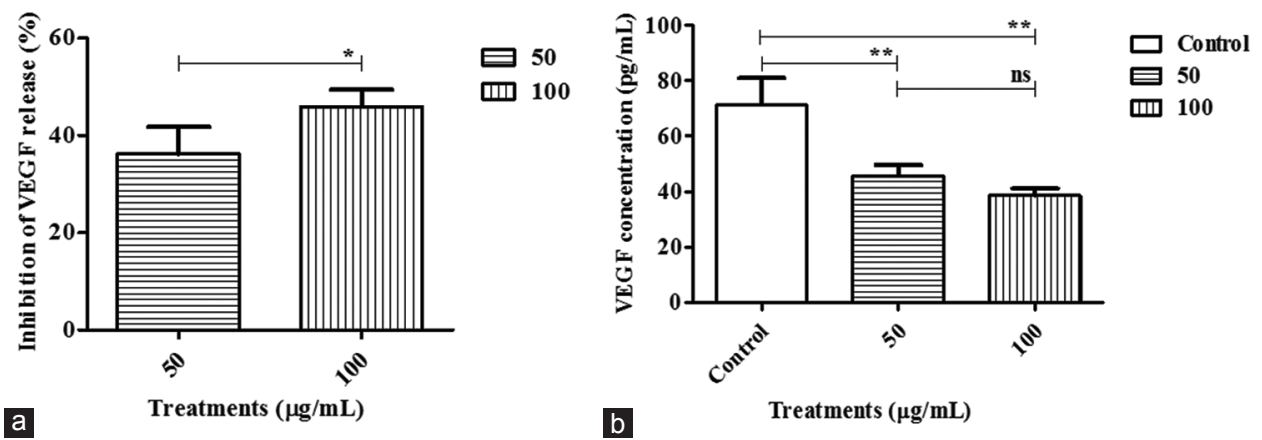

Figure 13: (a) Activity of SLs on the release of VEGF-A from EA.hy926 cells. Control $=0.5 \%$ DMSO and $100=100 \mu \mathrm{g} / \mathrm{mL}$ of SLs. (b) Concentration of VEGF-A from EA.hy926 cells. Control $=0.5 \%$ DMSO and $100=100 \mu \mathrm{g} / \mathrm{mL}$ of SLs. Values shown are presented as mean $\pm \mathrm{SD}(n=3) .{ }^{* *} P<0.01$, ${ }^{*} P<0.05$, and $\mathrm{ns}$ denotes $P>0.05$. $\mathrm{SLs}=$ Sophorolipids, $\mathrm{SD}=\mathrm{Standard}$ deviation, VEGF=Vascular endothelial growth factor, ns=Not significant 


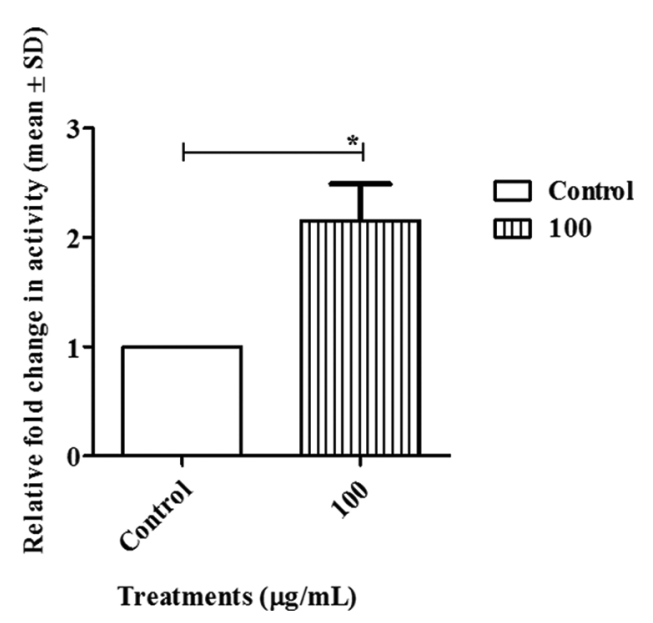

Figure 14: Activity of SLs on the expression of p53 transcription factor. Control $=0.5 \%$ DMSO and $100=100 \mu \mathrm{g} / \mathrm{mL}$ of SLs. Values are presented as mean $\pm S D(n=2) .{ }^{*} P<0.05$. SLs $=$ Sophorolipids, $S D=$ Standard deviation, DMSO $=$ Dimethyl sulfoxide

at high levels when required; for instance, during the development of embryo and in human tumors. In the present research, there was a dose-dependent trend observed in the release of VEGF as well as the percentage inhibition of the release. Therefore, SLs could possibly contribute toward its antiangiogenic property. It can be suggested that SLs have the capability to downregulate VEGF, especially VEGF-A release which in turn hinders the activation of EA.hy926 cells. Inactivation of the endothelial cells discontinues the cell colony formation, cell migration, and tube formation process. ${ }^{[14]}$ These multistep processes finally slowdown the outgrowth of new blood vessels, which are demonstrated in the rat aorta ring assay. ${ }^{[15]}$ In a recent study, a team of researcher has also demonstrated that some fatty acids can inhibit the angiogenesis process by downregulation of VEGF. ${ }^{[16]}$

p53 is a tumor suppressor protein which plays a major role in the angiogenesis process. ${ }^{[17]} \mathrm{P} 53$ may modulate the VEGF expression besides stimulating proteins to repair damaged DNA as an anticancer agent. ${ }^{[18]}$

Based on p53 fold changes obtained in the present research, it can be said that SLs might have upregulated the expression of p53 mRNA level toward antiangiogenic pathway and conclude in tumor inhibition. Overall, SLs upregulated p53 expression level which downregulated VEGF expression causing the inhibition of angiogenesis process.

\section{Conclusion}

Biosurfactants, especially glycolipid, are gaining more commercial interest due to its unique properties. This study demonstrated that SLs have yellowish texture in room temperature with PH of 5.5. FT-IR and UV-vis results confirmed the presence of alcoholic and aldehyde groups in the final product of fermented SLs. The majority of the compounds in SLs end product was revealed to be palmitic acid and oleic acid based on GC-MS analysis. Even though SLs did not demonstrate cytotoxic and significantly antioxidant effect, but it showed significantly antiangiogenic effect in vitro and ex vivo compared with suramin as approved drug. Moreover, downregulation of VEGF release and upregulation of P53 transcription factors confirmed the in vitro and ex vivo antiangiogenic effect of SLs.

Based on the results obtained, it can be concluded that SLs have promising potential to target cancer angiogenesis.

\section{Acknowledgment}

The authors would like to express their gratitude to the Malaysian Palm Oil Board, Universiti Sains Malaysia, EMAN Biodiscoveries Sdn. Bhd. and Natureceuticals Sdn. Bhd. companies for providing research facilities. We also gratefully acknowledge the financial support from the Ministry of Agriculture (MoA), Malaysia, under NKEA Research Grant Scheme; grant number: 304/PFARMASI/650735/K123 and 304/PFARMASI/650737/K123.

\section{Financial support and sponsorship}

Nil.

\section{Conflicts of interest}

There are no conflicts of interest.

\section{References}

1. Satpute SK, Zinjarde SS, Banat IM. Recent Updates on Biosurfactants in the Food Industry. In: Microbial Cell Factories. Florida: CRC Press; 2018. p. 1-20.

2. Jezierska S, Claus S, Van Bogaert I. Yeast glycolipid biosurfactants. FEBS Lett 2018;592:1312-29.

3. Varvaresou A, Iakovou K. Biosurfactants in cosmetics and biopharmaceuticals. Lett Appl Microbiol 2015;61:214-23.

4. Hassan LE, Dahham SS, Saghir SA, Mohammed AM, Eltayeb NM, Majid AM, et al. Chemotherapeutic potentials of the stem bark of Balanite aegyptiaca (L.) Delile: An antiangiogenic, antitumor and antioxidant agent. BMC Complement Altern Med 2016;16:396

5. Huang SC, Hsu CL, Lo JL, Chen YJ, Chan HT. Process of Producing Beverage by Fermenting Cactus Fruit and Pitaya: Google Patents; 2018.

6. Tan CS, Yam MF. Mechanism of vasorelaxation induced by $3^{\prime}$-hydroxy-5,6,7,4'-tetramethoxyflavone in the rats aortic ring assay. Naunyn Schmiedebergs Arch Pharmacol 2018;391:561-9.

7. Maolake A, Izumi K, Natsagdorj A, Iwamoto H, Kadomoto S, Makino $\mathrm{T}$, et al. Tumor necrosis factor- $\alpha$ induces prostate cancer cell migration in lymphatic metastasis through CCR7 upregulation. Cancer Sci 2018;109:1524-31.

8. Ma XJ, Li H, Shao LJ, Shen J, Song X. Effects of nitrogen sources on production and composition of sophorolipids by Wickerhamiella domercqiae var: sophorolipid CGMCC 1576. Appl Microbiol Biotechnol 2011;91:1623-32. 
9. Rau U, Hammen S, Heckmann R, Wray V, Lang S. Sophorolipids: A source for novel compounds. Industrial Crops and Products 2001;13:85-92.

10. Daverey A, Pakshirajan K. Production, characterization, and properties of sophorolipids from the yeast Candida bombicola using a low-cost fermentative medium. Appl Microbiol Biotechnol 2009;158:663-674.

11. Ahn C, Morya VK, Kim EK. Tuning surface-active properties of bio-surfactant sophorolipids by varying fatty-acid chain lengths. Korean J Chem Eng 2016;33:2127-33.

12. Keledjian K, Garrison JB, Kyprianou N. Doxazosin inhibits human vascular endothelial cell adhesion, migration, and invasion. J Cell Biochem 2005;94:374-88

13. Jabbarzadeh E, Eslambolchimoghada S. Pimarane Diterpenoids for Use in Wound Healing and Angiogenesis. Google Patents 2018.
14. Ferrara N, Hillan KJ, Gerber HP, Novotny W. Discovery and development of bevacizumab, an anti-VEGF antibody for treating cancer. Nat Rev Drug Discov 2004;3:391-400.

15. Ropraz P, Imhof BA, Matthes T, Wehrle-Haller B, Sidibé A. Simultaneous study of the recruitment of monocyte subpopulations under flow in vitro. J Vis Exp 2018;141:e58509.

16. Kulkarni YM, Dutta S, Iyer AK, Wright CA, Ramesh V, Kaushik $\mathrm{V}$, et al. A lipidomics approach to identifying key lipid species involved in VEGF-inhibitor mediated attenuation of bleomycin-induced pulmonary fibrosis. Proteomics Clin Appl 2018;12:e1700086.

17. Bergers G, Benjamin LE. Tumorigenesis and the angiogenic switch. Nat Rev Cancer 2003;3:401.

18. Williams AB, Schumacher B. p53 in the DNA-damage-repair process. Cold Spring Harb Perspect Med 2016;6:a026070. 
(C) 2019. This work is published under

https://creativecommons.org/licenses/by-nc-sa/4.0/(the "License").

Notwithstanding the ProQuest Terms and Conditions, you may use this content in accordance with the terms of the License. 